\title{
Studies on Physicochemical Analysis of Water from Different Sources
}

\author{
D. Keerthika, K. Gokulpriyan, I. Harini, Dr. V. Karthikeyan
}

\begin{abstract}
Department of Biotechnology, Karpaga Vinayaga College of Engineering and Technology, Padalam, Kanchipuram, Tamil Nadu,
\end{abstract} India

\begin{abstract}
Introduction: Water is one of the important natural sources for all living organisms. It is one of the ecological systems. It's the essential source for human health, food production and economic development. The quality of water is important is an important parameter to be noted. The quality of water is affected by various contaminants. The consumption of contaminated water may cause serious health problems due to the activity of microorganism present in it .Due to the activity of microorganism the quality of water becomes very poor and also causes harmful diseases. Thus in this study we are aimed to test the quality of water from different sources by means of physicochemical studies.
\end{abstract}

Objectives: The objective of the present studies is to provide information on the physicochemical characteristics \& detailed ecological studies of Portable water and Lake water (Habitat) in order to discuss it's suitability for human consumption. Physicochemical aspects of the water have been investigated to assess the quality of water.

Result: The variations of physicochemical properties and comparative analysis of water different sources were analyzed.

Keywords- Biochemical aspects, Ecological system, habitat, physicochemical studies.

\section{INTRODUCTION}

Water is one of the important natural sources for all living organisms. It is one of the ecological systems. It's the essential source for human health, food production and economic development (1). The quality of water is important is an important parameter to be noted. The quality of water is affected by various contaminants $(2,4)$. The consumption of contaminated water may cause serious health problems due to the activity of microorganism present in it $(2,4)$.Due to the activity of microorganism the quality of water becomes very poor and also causes harmful diseases. Thus in this study we are aimed to test the quality of water from different sources by means of physicochemical studies $(6,10,14)$.

\section{Sample Collection:}

Portable water sample was collected from five different areas of Kanchipuram.

Habited water sample was collected from four different lakes of Kanchipuram, Mathuranthagamn Lake, Kolavai Lake, Karunguzhi Lake and Vedanthangal Lake.

\section{Material and Methods}

The water sample was collected from four different lakes for the project work. The sample was taken in a closed bottle was dipped into the lake and opened the cap inside the lake and was closed again to bring it out at the surface (9). From the time of sample collection, biological and chemical reactions may change the quality of water sample. To minimize the growth of microorganism, we have to preserve soon after the collection of water sample $(13,9)$. Once the water sample is collected, the odour, taste and TDS should be analyzed and preserved by adding chemical preservations and lowering its temperature (13). The water analysis process was carried out for a period of four months. The collected water samples were brought to the laboratory and analysis were performed. $\mathrm{pH}$ was determined using $\mathrm{pH}$ meter, and similarly turbidity is measured by turbiditymeter (Verma Pradeep et al, 2012). 


\begin{tabular}{|c|c|c|c|c|c|c|}
\hline $\begin{array}{c}\text { Sr. } \\
\text { No. }\end{array}$ & Test & $\begin{array}{c}\text { Processed } \\
\text { Water } \\
\text { Sample }\end{array}$ & $\begin{array}{c}\text { Chengalpet } \\
\text { Municipal } \\
\text { Water Sample }\end{array}$ & $\begin{array}{c}\text { Madhuranthaga } \\
\text { m } \\
\text { Municipal } \\
\text { Water } \\
\text { Sample }\end{array}$ & $\begin{array}{c}\text { Vedanthangal } \\
\text { municipal } \\
\text { Water } \\
\text { Sample }\end{array}$ & $\begin{array}{c}\text { Kolavai } \\
\text { Municipal } \\
\text { Water } \\
\text { Sample }\end{array}$ \\
\hline 1 & Temperature $\left({ }^{\circ} \mathrm{C}\right)$ & 28 & 28 & 28 & 28 & 28 \\
\hline 3 & Odour & Agreeable & Agreeable & Agreeable & Agreeable & Agreeable \\
\hline 4 & Taste & Agreeable & Agreeable & Agreeable & Agreeable & Agreeable \\
\hline 5 & $\mathrm{pH}$ & 6.9 & 7.0 & 6.9 & 6.8 & 7.0 \\
\hline 6 & Turbidity (NTU) & 0.38 & 0.29 & 0.30 & 0.28 & 0.30 \\
\hline 10 & Alkalinity (ppm) & 8 & 8 & 9 & 8 & 10 \\
\hline 11 & Chloride (ppm) & 58 & 30 & 41 & 33 & 35 \\
\hline 12 & Calcium (ppm) & 6.2 & 7 & 6 & 8 & 7 \\
\hline 13 & Barium (ppm) & Nil & Nil & Nil & Nil & Nil \\
\hline 14 & Magnesium (ppm) & 2.2 & 3 & 3 & 3.5 & 2.5 \\
\hline 15 & Total Hardness (ppm) & 4 & 4.5 & 4.5 & 5 & 4.9 \\
\hline 16 & Copper (ppm) & 0 & 0 & 0 & 0 & 0 \\
\hline 17 & Sulphate (ppm) & 8 & 10 & 14 & 16 & 11 \\
\hline
\end{tabular}

Table 2: Lake Water Samples

\begin{tabular}{|l|l|l|l|l|l|}
\hline $\begin{array}{l}\text { S. } \\
\text { No. }\end{array}$ & Test & $\begin{array}{l}\text { Chengalpet } \\
\text { Lake Sample }\end{array}$ & $\begin{array}{l}\text { Mathuranthagam } \\
\text { Lake Sample }\end{array}$ & $\begin{array}{l}\text { Vedanthangal } \\
\text { Lake sample }\end{array}$ & $\begin{array}{l}\text { Kolavai } \\
\text { Lake Sample }\end{array}$ \\
\hline $\mathbf{1}$ & Temperature & 28 & 27 & 29 & 28 \\
\hline $\mathbf{2}$ & Colour (Unit) & $<2.3$ & $<3$ & $<2.5$ & $<3$ \\
\hline $\mathbf{3}$ & Odour & Disagreeable & Disagreeable & Disagreeable & Disagreeable \\
\hline $\mathbf{4}$ & Taste & Disagreeable & Disagreeable & Disagreeable & Disagreeable \\
\hline $\mathbf{5}$ & pH & 8.3 & 8.6 & 8.7 & 8.8 \\
\hline $\mathbf{6}$ & Turbidity (NTU) & 8 & 9 & 11 & 10 \\
\hline $\mathbf{7}$ & TDS (ppm) & 900 & 946 & 987 & 735 \\
\hline $\mathbf{8}$ & $\begin{array}{l}\text { Dissolved oxygen } \\
\text { (ppm) }\end{array}$ & 5.7 & 5.9 & 4.4 & 5.0 \\
\hline $\mathbf{9}$ & $\begin{array}{l}\text { Dissolved carbon-di- } \\
\text { oxide(ppm) }\end{array}$ & 7.0 & 6.9 & 6.6 & 6.1 \\
\hline $\mathbf{1 0}$ & Alkalinity (ppm) & 150 & 168 & 164 & 170 \\
\hline $\mathbf{1 1}$ & Chloride (ppm) & 84 & 83 & 60 & 74 \\
\hline $\mathbf{1 2}$ & Calcium (ppm) & 72 & 73 & 68.6 & 67 \\
\hline $\mathbf{1 3}$ & Barium (ppm) & 41 & 32 & 31 & 36 \\
\hline $\mathbf{1 4}$ & Magnesium (ppm) & 32 & 15.2 & 7.8 & 8.2 \\
\hline $\mathbf{1 5}$ & Total Hardness (ppm) & 280 & 279 & 343 & 321 \\
\hline $\mathbf{1 6}$ & Copper (ppm) & 19.76 & 15.27 & 17.43 & 15.89 \\
\hline $\mathbf{1 7}$ & Sulphate (ppm) & 74 & 62 & 61 & 71 \\
\hline
\end{tabular}




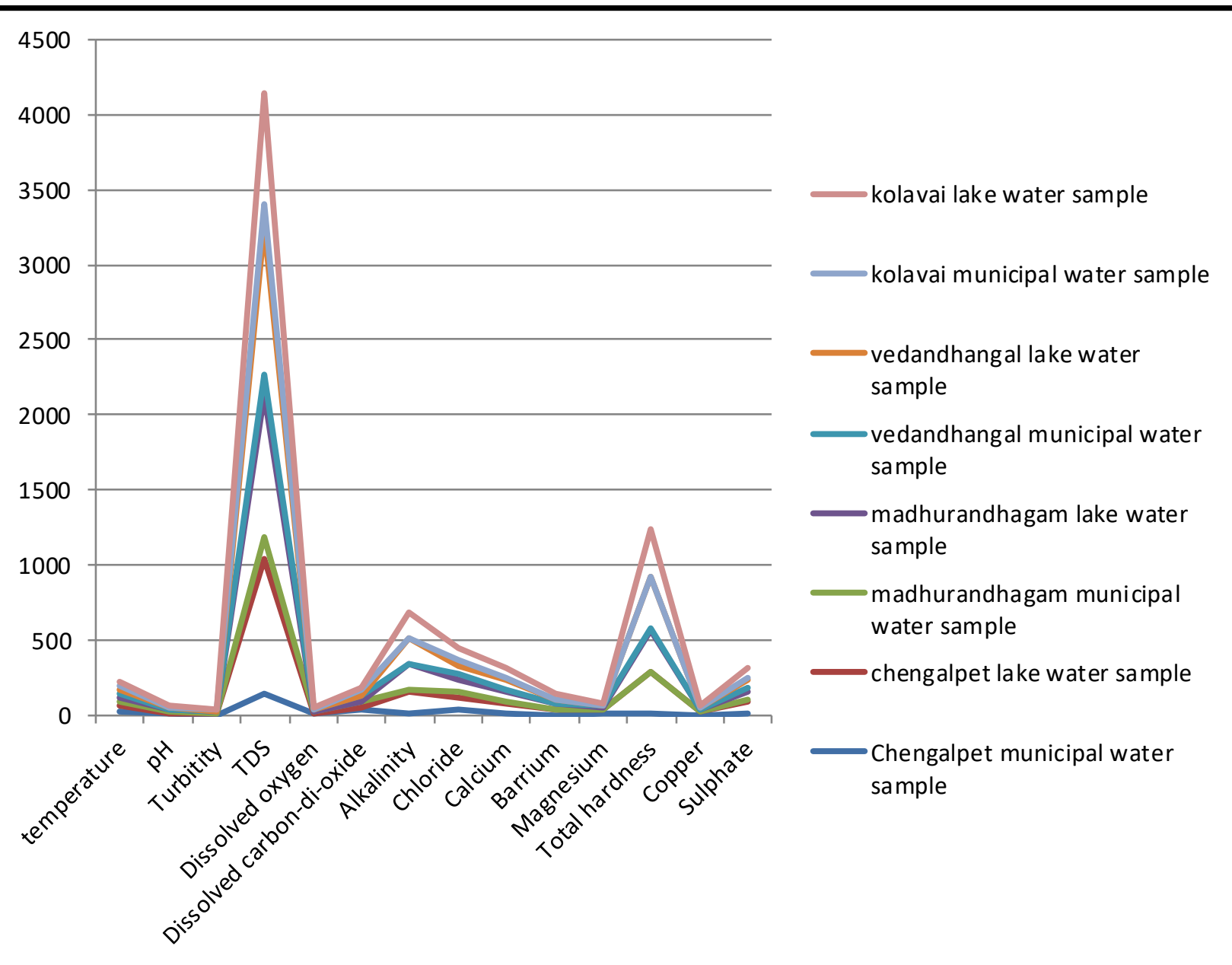

Fig.:1: Comparative graph for municipal water sample and lake water sample

\section{DISCUSSION}

Physical parameters like Odour \& Taste was agreeable in portable water. The general ISI standard for Drinking water's Turbidity is 5 NTU is considered unhealthy (2). In Different areas of portable water the Turbidity ranging from 0.2 NTU to 0.4 NTU (13). In Municipal water, observed higher Turbidity than other area. The normal $\mathrm{pH}$ range of drinking water is between 6.5 to 7.0. The $\mathrm{pH}$ municipal water was observed between 6.5to7.0. So that the criteria of $\mathrm{pH}$ range was acceptable. For Portable water, Dissolved carbon dioxide \& Dissolved oxygen were found to be 6.2 and 38 (Average value of five different areas) respectively (8). TDS of water sample showed range below $1000 \mathrm{ppm} \&$ it complied with the given criteria of Indian standard. Minerals like Calcium, Magnesium, Chloride, Sulphate, Barium, and Copper are essential for human body. Tests of these minerals were performed on portable water sample (9). The results complied with the given range to be Test for Minerals. Alkalinity \& Total Hardness of potable water samples should less than or equal to 10 and $300 \mathrm{ppm}$ respectively (13). Results were complied with the given limits of both tests. Turbidity of lake water sample ranges from 4 NTU to 11 NTU. The Total dissolved solid recorded ranges from $668 \mathrm{ppm}$ to $942 \mathrm{ppm}$.

\section{CONCLUSION}

The result obtained during study was compared with ISI standards. Portable water is water safe enough to be consumed by the humans and the habited water is generally used by animals \& birds \& aquatic life. After physicochemical analysis we found that the sample of Portable water and habited water are free from pollution \& ecologically balanced.

\section{REFERENCES}

[1] Devangee shukla, Kinjal Bhadresha, Dr. N. K. Jain , Dr. H. A. Modi ;Physicochemical Analysis of Water from Various Sources and Their Comparative Studies. 
[2] Basavaraja Simpi, S.M. Hiremath, KNS Murthy, K.N. Chandrashekarappa, Anil N Patel, E. T. Puttiah; Analysis of Water Quality Using Physico Chemical Parameters Hosahalli Tank in Shimoga District, Karnataka, India; Global Journal of Science Frontier Research,11(3),2011.

[3] Bhaven N. Tandel, Dr. JEM Macwan, and Chirag K. Soni, Assessment of Water Quality Index of Small Lake in South Gujarat Region, India.

[4] Basavaraja Simpi, S.M. Hiremath, KNS Murthy, K.N. Chandrashekarappa Anil N Patel, E.T. Puttiah; Analysis of Water Quality Using Physico-Chemical Parameters Hosahalli Tank in Shimoga District, Karnataka, India; Global Journal of Science Frontier Research, 11(3); 2011.

[5] Hydrology project; Government of India \& Government of The Netherlands; Standard Analytical Procedures for Water Analysis May 1999.

[6] Indian Standard Specifications for Drinking Water, IS: 10500,1992

[7] Jamie Bartram and Richard Ballance, Physical And Chemical Analyses.

[8] Jin Hur , Bo-Mi Lee, Tae-Hwan Lee and Dae-Hee Park ; Estimation of Biological Oxygen Demand and Chemical Oxygen Demand for Combined Sewer Systems Using Synchronous Fluorescence Spectra; Sensors 2010, 10, 2460-2471.

[9] Kawther F. Abed and Suaad S. Alwakeel; Mineral and Microbial Contents of Bottled and Tap Water in Riyadh, Saudi Arabia; Middle-East Journal of Scientific Research, 2 (3-4): 151-156, 2007.

[10] Krishna Vaidya and Mohini Gadhia; Evaluation of drinking water quality; African Journal of Pure and Applied Chemistry, 6(1):6- 9, 102012.

[11] M.M. Aldaya and M.R. Llamas;water footprinting analysis for the Guadiana River basin; November 2008 Value of Water Research Report Series No. 35.

[12] Murhekar Gopalkrushna H; International Journal of Research in Chemistry and Environment; Murhekar Gopalkrushna Int. J. Res. Chem. Environ. 1(2)2011(183-187).

[13] O. A. Ojo, S. B. Bakare and A. O. Babatunde; Microbial and Chemical Analysis of Potable Water In Public - Water Supply, Afr. J. Infect. Dis. 1(1): $30-$ 35.

[14] O. Akoto; J. Adiyiah; Chemical analysis of drinking water from some communities in the Brong Ahafo region; Int. J. Environ. Sci. Tech., 4 (2): 211-214, 2007. 